\title{
INCREASING THE EFFICIENCY OF DEFINING THE ELEMENTS OF TRAFFIC SIGNALIZATION CYCLE
}

\author{
Denisenko O. V., Kharkiv National Automobile and Highway University
}

\begin{abstract}
Problem. A new approach of defining the parameters of vehicle traffic and features of organizing the traffic flows (TF) monitoring to optimize the parameters of traffic signalization (TS) cycle has been considered. Goal. Increasing the efficiency of defining the elements of TS cycle and expanding the functionality of the common technique, receiving a full set of data to monitor and to control online the traffic at the intersection. Methodology. The method and the algorithm of defining the elements of TS cycle within the conditions of on-line changing the parameters of traffic flows and system adaptive response to a situation have been suggested. The possibilities of increasing the efficiency of measurements at the expense of multibeam laser scanning the intersection zone that provides increasing the accuracy of defining the cycle elements and cycle optimization have been analyzed. Results. It has been suggested to define the elements of regulation cycle according to accurate measurements to make possible reducing losses of time in the cycle and increasing the efficient operation time of phases. The developed structure of the device for implementing the suggested technique has been presented. The feasibility and sustainability of the algorithms included in this technique have been shown. Originality. The original innovative technique of TF control at the signalized intersection patented in Ukraine has been suggested. Practical value. The advantages of our suggested technique have been presented. The additional options of forecasting TF conditions at the intersection and criteria of TS quality control can be defined simultaneously in it. The flexible technique and integrated assessment of TS modes allow carrying out the combined adaptive control at the intersection in real time.
\end{abstract}

Key words: traffic flow, vehicle, signalized intersection, scanning device, laser beam, cycle.

\section{Introduction}

One of the most important areas of road traffic (RT) is constructing the control system at such important elements of street and road network (SRN) as signalized intersections. To ensure a high level of control and organizational measures at signalized intersections one requires data characterizing not only the TF but the possibility to obtain the criterion of quality control of intersection work [1].

One of the main objectives of such systems is to determine a wide range of $\mathrm{TF}$ parameters that can be achieved by providing the complex diagnostics with reliable, multifunctional and rather cheap traffic condition detectors of TF on highways and intersections that allow to determine simultaneously the overall dimensions of the vehicle, the points of passing the control zones (CZ) and the intersection on the whole, the speed, the type and vehicle driving directions, vehicle density on each lane at any time interval, traffic intervals between vehicles, their delays and $\mathrm{TF}$ combinations.

Full-scale studies, traffic simulation, TF video monitoring, etc. should be marked among the current research methods of TF parameters. All these methods aim at obtaining accurate data on TF parameters for efficient vehicle traffic control.

Then extensive studies on using a variety of radio electronic, optical and vehicle ultrasonic detectors to determine a wide range of $\mathrm{TF}$ parameters were carried out $[2,3]$.

At the same time intersection monitoring systems used in developing RT control tools of the aggregate system, ACS-RT, information support systems of SRN intersection load and increasing the efficiency of vehicle traffic control at signalized intersections were developed extensively.

Therefore, the task of developing and improving modern vehicle detectors and intersection monitoring systems is important and relevant.

\section{Analysis of Publications}

Analysis of publications shows the availability of a big number of devices including vehicle detectors for defining TF parameters on the ways to the intersection among which the most specialists give preference to methods and means of using optical (laser) light nowadays.

Thus in work [2] an opto-electric vehicle detector based on the table-like rasters was suggested as a signal receiver. Initial data of this detector are speed, overall dimensions (height, 
length), and $\mathrm{TF}$ basic characteristics using a vehicle-marker.

The disadvantage of this device is the complexity of video processing revealing the optical image of the vehicle because the values of signal amplitude maxima may vary depending on the vehicle illumination and its speed. Therefore, it is necessary to carry out calibration (to adjust a correction coefficient) constantly and standardization of reflected signal amplitude resulting in additional temporary expenditures.

Common methods and devices for defining vehicle speed and type using cameras mounted in the control device as a part of domestic and foreign devices (Arena, Kris-1, Vizyr, Sokil, TruCam, etc.) [3].

Operational experience of such systems shows that they have a number of disadvantages including: the high cost and complexity of special software to process video data, the necessity of satisfactory illuminating the controlled zone at night; a long period of data processing used for forming the control actions and their transfer to SRN at pace compatible with the rate of changing traffic conditions; impossibility of defining all $\mathrm{TF}$ necessary parameters on all lanes of the intersection simultaneously and possibility of full automation of decision making in real time.

The process of building such systems is a complex technological chain including digital signal processing to form and analyze these data to solve the required problem. Constructing the universal adaptive system that within possible constraints could ensure the effective object monitoring may be ideal version in this case [4].

Currently among common techniques that mostly meet abovementioned requirements we can select the method of defining the traffic flow parameters at the intersection zone according to which the conical step-by-step scanning infrared range of all its entrances and exits with a straight laser beam occurs in the spatial intersection zone [5].

This method allows to measure a set of parameters for further defining TS cycle elements on all the lanes simultaneously on-line: the speed and directions of the vehicle at the intersection zone, vehicle traffic intervals and vehicle overall dimensions, TF density on each lane.

The disadvantage of this technique and the corresponding device is its limited functionality that makes impossible defining such important $\mathrm{TF}$ parameters at the intersection as: vehicle queues on each lane at red traffic light, a vehicle type, reduction factors to the car, saturation flows, phase coefficients, etc. All this significantly limit the possibility to obtain the most complete set of data for control and further operational (on-line) exact defining operation time of main and intermediate steps (MS, IS), traffic control cycle at the intersection at optimal mode.

Besides a well-known method within this technology while measuring does not allow to use simultaneously the criteria for estimating the efficiency of signalized intersection control such as the vehicle average delay, lane saturation rate and intersection capacity that reduce its functionality substantially.

\section{Purpose and Tasks}

To increase the efficiency of defining TS cycle elements it was necessary to solve the following tasks:

- analysis of current and development of new methods, techniques and algorithms to monitor TF at signalized intersections;

- expanding the functionality of a known technique to obtain a complete set of data for controlling and better operational defining the optimal values of IS, MS operation time, traffic control cycle at the intersection;

- a proposal and developing such a technique that meets the requirements of a universal adaptive system responding to any changes under $\mathrm{TF}$ various traffic conditions at the intersection in real time efficiently.

\section{Substance of the Proposal}

The goal is achieved by using a conical stepby-step simultaneous scanning all entrances and exits of the intersection with three straight laser beams temporarily (see Fig. 1). The suggested technique makes possible to form entrance and exit borders of two $\mathrm{CZ}$ and provide defining a set of TF necessary elements on each lane, MS, IS and TS cycle depending on scan results [6].

According to the suggested technique laser beam scanning is performed by scanning device 1 , mounted on a special support over the intersection at the point of correspondence with the geometric centre of the intersection. In the scanning device one of the scanning optical axes depending on its height level is selected so that the first laser beam can circle the conical surface on the intersection roadway $\left(\mathrm{R}_{1}\right)$ within «stop lines» of all its entrances.

The scanning device includes an optical deflective device (discrete scanistor) providing an axis deviation of the first laser beam to the desired second position in which the circle radius $\left(R_{2}\right)$ on the roadway is reduced by the specified value (e.g. $1 \mathrm{~m}$ ). 


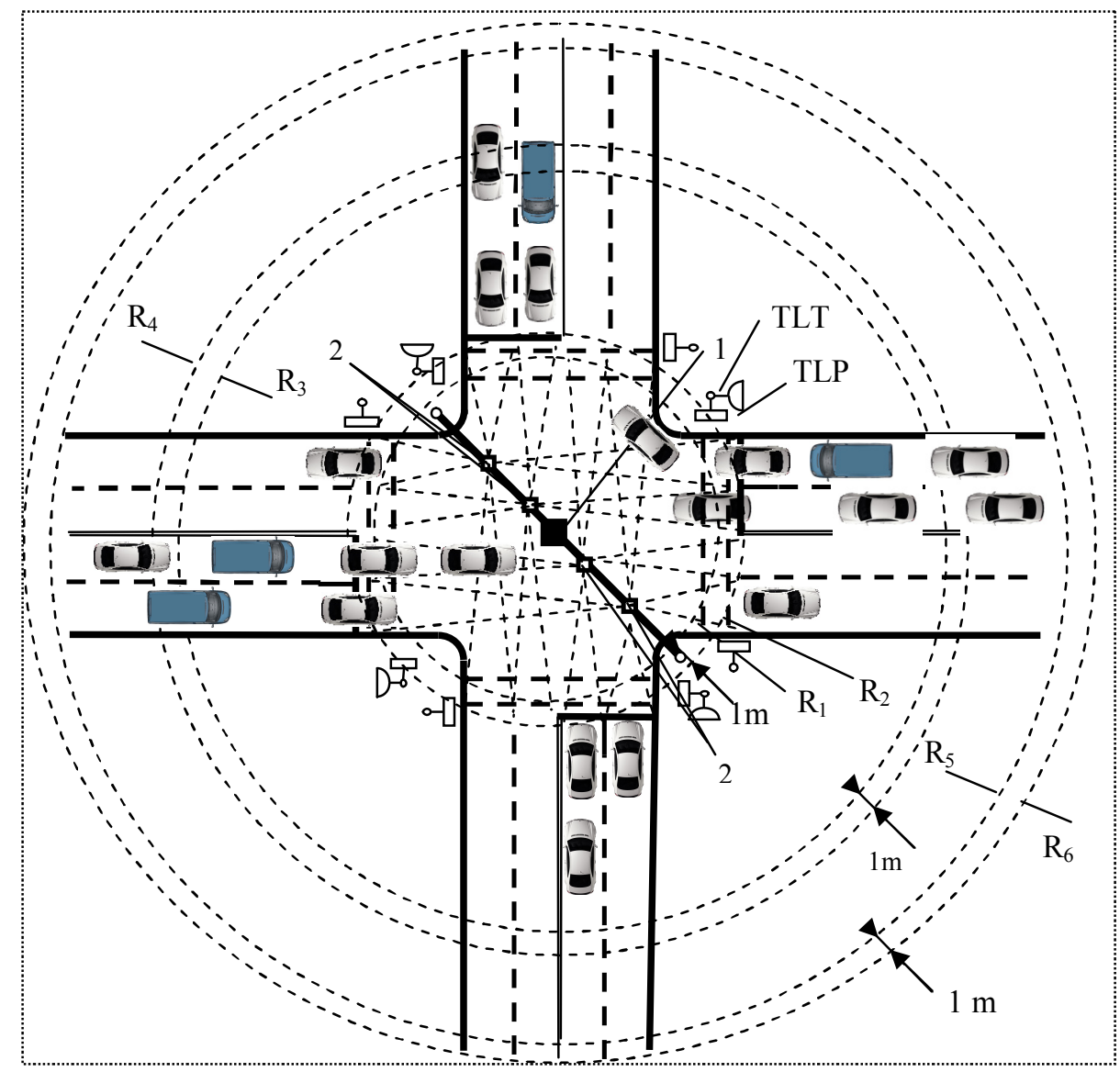

Fig. 1. A scheme revealing the main features of the suggested technique

Thus, at each next scanning period the scanning device changes the first laser beam scanning from one optical axis to another and draws two concentric circles with radii difference $\left(R_{1}-\right.$ $R_{2}=1 \mathrm{~m}$ ) within the stop-lines at intersections and forms the $\mathrm{CZ}$ exit border.

The second optical beam of laser scanning is formed with $120^{\circ}$ shift in scanning circle (see fig. 2) and forms the first $\mathrm{CZ}$ entrance border. This beam like the first one at each next scanning period changes one optical scanning axis (with circle radius $R_{3}$ ) to another (with radius $R_{4}$ ) with the corresponding discrete scanistor $5_{2}$ and forms two concentric circles with radii difference $R_{4}-R_{3}=1 \mathrm{~m}$.

The third optical beam of laser scanning is $120^{\circ}$ shifted relative to the other in scanning circle and forms the second $\mathrm{CZ}$ entrance border. This beam like two other at each next scanning period changes one optical scanning axis (with circle radius $R_{5}$ ) to another (with radius $R_{6}$ ) with the corresponding discrete scanistor $5_{3}$ and forms two concentric circles with radii difference $R_{6}-R_{5}=1 \mathrm{~m}$.

Optical photodetectors $2\left(\mathrm{FD}_{\mathrm{i}}\right)$ while laser beams $8_{1}, 8_{2}$ and $8_{3}$ scanning at both $\mathrm{CZ}$ entrance circle and $\mathrm{CZ}$ exit circle receive signals reflected from the vehicle driving on different lanes both at intersection entrances and exits consequently. Temporal and spatial diversity of laser beams allow to record all scanning signals on the corresponding lane by one FD.

Recording vehicles entering both $\mathrm{CZ}$ is performed according to their front bumpers when crossing one of the circles (e.g. $R_{6}$ or $R_{4}$ ), at the same time an entry point, speed, length, a type, quantity and sequence of vehicles that actually entered the $\mathrm{CZ}$ on each lane during the measuring period are determined at a distance of $1 \mathrm{~m}$ due to periodic scanning with the optical axis change of the laser beam (from radius $R_{3}$ to $R_{4}$ and vice versa, and from $R_{5}$ to $R_{6}$ )

Radius $\mathrm{R}_{3}$ forming the first CZ entrance border is selected if the distance between $R_{3}$ and $R_{1}$ (considering the actual distance at which the driver responds to traffic light changes) meets the maximum possible braking path (BP) of different vehicles crossing the entrance border of the first $\mathrm{CZ}$ with a maximum authorised speed $(50 \mathrm{~km} / \mathrm{h})$.

This allows you to determine the vehicle speed at the entrance of the first $\mathrm{CZ}$ at the point 
of traffic lights changing from green to yellow and to calculate its BP according to the vehicle speed and type and finally to make a decision about finishing the IS

$$
l_{s p}=l_{r t}+l_{s d}=V \cdot t_{r t}+\frac{V^{2}}{2 g(\varphi+f \pm \lambda)},
$$

where $l_{r t}$ - the travel of the vehicle while driver reaction time $t_{r t}$ to traffic lights changing; $l_{s d}-$ braking path; $V$ - the speed of the vehicle at $\mathrm{CZ}$ entrance; $g$ - gravitational acceleration; $\varphi$ - the coefficient of longitudinal adhesion of wheels; $f$-coefficient of running the wheel; $\lambda$ - the value of longitudinal slope.

Double scanning in stop-lines area and on the corresponding lanes at the intersection exit by the first beam allows us to define all the above mentioned parametres of vehicles left $\mathrm{CZ}$ on each lane at a green traffic light and completely left the intersection zone.

This allows us to obtain the accurate data about vehicle presence on separate lanes in $\mathrm{CZ}$ at the point of traffic lights changing to yellow and determine the number and type of vehicles that couldn't leave the intersection zone at a green traffic light, i.e. they did not cross the scanning scan $\left(R_{1}, R_{2}\right)$ on lanes at the intersection exit. This is possible when the left-turning vehicles in the intersection zone are waiting for direct oncoming vehicle passing and the rightturning vehicles -the pedestrian traffic ending.

The data on the length, type and the quantity of vehicles in the intersection zone at the starting point the IS make it possible to define a point when all the vehicles from the previous phase of traffic leave the intersection zone to start a new phase. It is proposed to realize at points when the last vehicle presented in the intersection zone starts to cross one of the scanning lines (e.g., $\mathrm{R}_{1}$ ) on the lanes at the intersection exit by its front bumper. This ensures that the last vehicle has reached or passed the farthest conflict point of this IS and subject to availability of data on its length, has almost left the intersection.

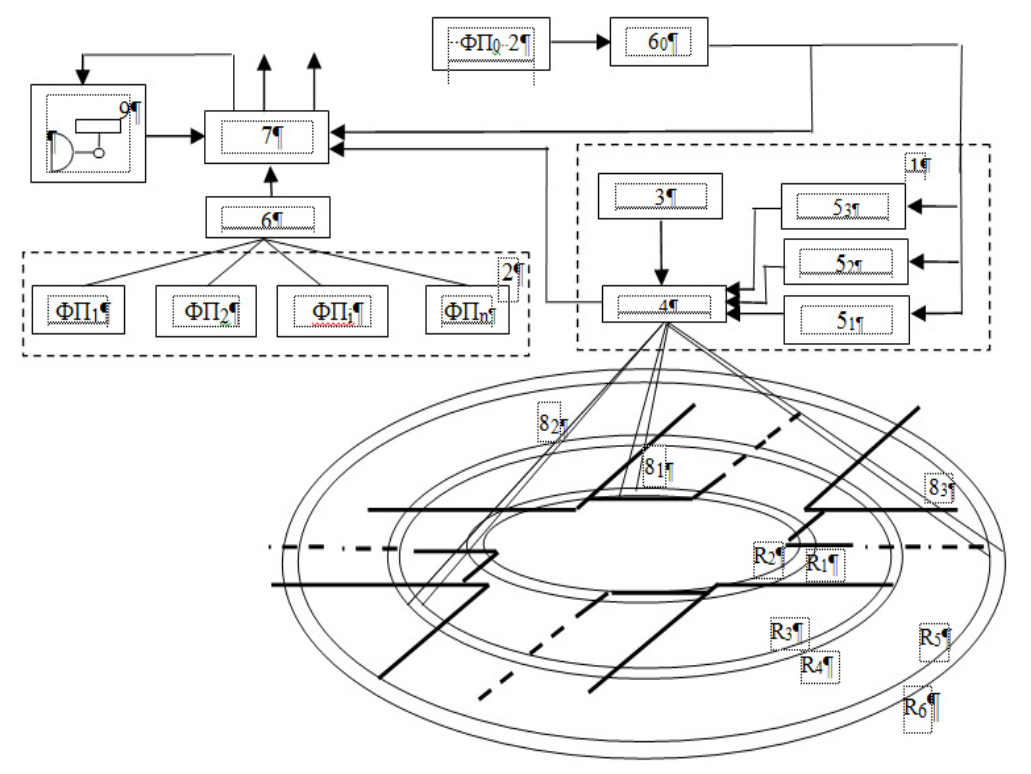

Fig. 2. The simplified block diagram of the device revealing the suggested technique

The point of crossing the scanning line with radius $R_{1}$ by its front bumper is taken as the IS end of this phase, but subject to checking the presence of a new vehicle, with braking path exceeding the $\mathrm{CZ}$ length at the entrance of the first CZ. This is possible only if at the starting point of IS the vehicle crosses the first $\mathrm{CZ}$ entrance border at a speed exceeding the limit (over $60 \mathrm{~km} / \mathrm{h}$ ) and its type and overall dimensions prove that its BP exceeds the $\mathrm{CZ}$ length and this vehicle enters the intersection zone even with full braking. In this case, the IS end is de- termined by the point of crossing the scanning line with radius $R_{1}$ at the intersection exit by the front bumper of the vehicle.

Recording vehicles entering the second $\mathrm{CZ}$ is performed according to their rear bumpers when crossing one of the circles (e.g. $R_{5}$ ), at the same time an entry point, speed, length, a type, quantity and sequence of vehicles that actually entered the second $\mathrm{CZ}$ on each lane during the measuring period are determined due to periodic scanning with the optical axis change of the laser beam. Radius $\mathrm{R}_{5}$ forming the second $\mathrm{CZ}$ en- 
trance border is desirably selected provided that it exceeds the most possible vehicle queue that can be on one of the lanes at a red traffic light under normal conditions. This enables to determine the number of vehicle $m_{j}$ in a queue on each $j^{\text {th }}$ lane at the intersection entrances at the point of traffic lights changing to green, or at the point of starting the traffic of the first vehicles in the queue accurately enough.

The data on the length, type and the travel time of vehicles at the entrance of the second CZ make it possible to define the real value of reduction factors to the car $K_{R i}$ as the ratio of average time interval $\bar{t}_{c i}$ of vehicle particular type travel on the circle with $R_{5}$ by the front bumper first and by the rear one then to the average value of similar time interval $\bar{t}_{p i}$ of the car travel

$$
K_{R i}=\bar{t}_{c i} / \bar{t}_{p i}
$$

Measuring a set of the parameters in the intersection zone also enables to determine the combination and the length of vehicle queues gathered before the stop line at a red traffic light on each lane both in physical and reduced units

$$
N_{R j}=K_{R 1} N_{1}+K_{R 2} N_{2}+\ldots+K_{R i} N_{i},
$$

where $N_{R j}$ - the number of vehicles in reduced to cars units on the $j^{\text {th }}$ lane; $N_{i}$ - the number of vehicle types $i$ in the queue on the $j^{\text {th }}$ lane; $K_{R i}-$ reduction factor of vehicle type $i$ to the car.

All this enables to increase the accuracy of calculations and forecasting first, and with the first beam to determine the exact time $T_{j}$ of queue travel on each lane at a green traffic light and the operation time of each MS according to the scanning results of $\mathrm{CZ}$ exits then.

Operation time of each MS $T_{o i} i$-phase is defined by the ending point of travel the most time-consuming queue on the lanes in this control phase. Fixing the MS end point is carried out by the point of crossing the scanning line with radius $\mathrm{R}_{1}$ by its rear bumper of the last vehicle in the queue provided that at this point all vehicles leave the first $\mathrm{CZ}$ completely. Otherwise, the end of the MS is formed as a maximum value fixed in advance.

The operation time $T_{c}$ of TS cycle is defined as a set of main $T_{o i}$ and intermediate $T_{n i}$ steps of all the phases according to the scanning results

$$
T_{c}=\sum_{i=1}^{m} T_{o i}+\sum_{i=1}^{m} T_{n i}
$$

The simplified block diagram of the device to implement the suggested technique includes: scanning device 1 , straight beam laser emitter 3 and scanning unit 4 , that form three-beam conical step-by-step scanning the intersection zone using optical deflection devices $5_{1}, 5_{2}$ and $5_{3}$. The shifts in the angles of scanning beams $8_{1}, 8_{2}$ and $8_{3}$ are performed at the control point of in turns at each interval of scanning the signal coming from the fixed photodetector $2\left(\mathrm{FD}_{0}\right)$ to inputs of discrete scanistors $5_{1}, 5_{2}$ and $5_{3}$.

Photodetectors 2, directed to entrance and exit traffic lanes receive consequently reflected signals from all the laser beams with a third scanning period time delay.

Transducer 6 of each FDi signal of the corresponding lane converts signals into pulse-digital codes input into the computing device (CD) 7 , which further defines all necessary parameters at any measuring time (operation time of MS, IS or TS cycle). To do this signals of changing TS cycle elements from the output of traffic light 9 are fed to the appropriate $\mathrm{CD}$ input.

The signals from the $\mathrm{FD}_{0}$ fixed output through converter $6_{0}$ are fed to the corresponding inputs of discrete scanistors $5_{1}, 5_{2}, 5_{3}$ and $\mathrm{CD}$ to determine the position of each beam on the lanes relative to fixed points. During the control cycle CD stores the data on the type, quantity and directions of vehicles that are in the $\mathrm{CZ}$ or in the intersection zone at the start point of MS and IS. The algorithm and some constants to calculate BP of various vehicles by means of which full braking of the vehicle to a stop line is determined, reduced factors to cars for precalculating the time of vehicle queue travel are built in CD.

After the last vehicle that was in the intersection zone from the beginning of the IS, crosses scanning line $\mathrm{R}_{2}$ by its front bumper at the intersection exit $C D$ gives the signal of IS finishing into traffic light 9. If there is no vehicle in the intersection zone at the IS starting point the computing device generates the signal of IS finishing in minimum time fixed in advance designed, for example, to finish the pedestrian traffic.

The computing device also determines the points of MS finishing under various traffic conditions of $\mathrm{TF}$ at the intersection.

Thus, the on-line defining the real parameters of certain types vehicle travel on all lanes at the intersection entrances and in intersection zones by a three-way high speed scanning enables to obtain (in real time) the precise value of MS, IS operation time and increase the efficiency of 
control by optimizing the parametres of TLS cycle for specific conditions.

Defining the operation time of MS and IS on precise measurements rather than rough calculations on average values of parameters in some cases allows to reduce steps, wasted time in the control cycle and increase the efficient length of the signalized phases. This is possible if there is no vehicle in the intersection zone and its entrances at IS starting point.

Reducing the MS is possible if there is no vehicle in allowed directions within MS operation time, or if there is no vehicle in separate directions like in split-phase control. Fixing the end point of IS when the last vehicle leave the exit of the intersection zone increases the efficiency of control by improving safety at the signalized intersection.

\section{Conclusion}

The suggested technique makes possible to obtain the most complete set of data for control and on-line defining the optimal values of MS and IS operation time, traffic control cycle, to contribute to increasing the efficiency of operation and traffic capacity of signalized intersections and transport network as a whole.

The suggested technology of measuring a set of TF travel parameters allows to assess the quality of TS by such criteria as vehicle average delays, lane saturation rate, and intersection capacity and to control the quality of TS in real time simultaneously.

This issue expands the functionality of the technique and its efficiency significantly and in real life (under rapid changing traffic conditions at the intersection) enables to perform both control parametric adaptation (optimizing the elements of the cycle) and structural or combined adaptation by restructuring the traffic control schemes.

\section{Conflict of Interests}

The author declares that there is no conflict of interests regarding the publication of this paper.

\section{References}

1. Левашев А.Г. Проектирование регулируемых пересечений: учеб.пос. / А.Г. Левашев, А.Ю. Михайлов., И.М. Головних. Иркутск: Изд-во ИрГТУ, 2007. - 208 с.

2. Плешенцев В.С. Диагностирование транспортных потоков федеральной автотрассы «Волга М-7» / В.С. Плешенцев, Е.В Дмитриева, Д.А Соцков // Организа- ция и безопасность дорожного движения в больших городах: сборник статей 7-й международной научно-практической конференции, посвященной 70-летию МВД России. - Санкт-Петербург, 21-22 сентября 2006. - С. 27-31.

3. Барский И.В. Комплекс регистрации изображения и скорости (КРИС-1) / И.В. Барский // Организация и безопасность дорожного движения в больших городах: сборник статей 7-й международной научнопрактической конференции, посвященной 70-летию МВД России. - Санкт-Петербург, 21-22 сентября 2006. - С. 157-159.

4. Лукьяница А.А. Программный комплекс для мониторинга транспортных средств по видеоизображению / А.А. Лукьяница, А.Г. Шишкин // International Conference Graphicon 2006. - Novosibirsk Akademgorodok, Russia. - Режим доступа: http://www.graphicon.ru.

5. Пат. 71913 Україна, G 08 G 1/09. Спосіб визначення параметрів транспортних потоків у зоні перехрестя / Левтеров А.I., Денисенко О.В., Ярута А.М.; заявник і патентовласник Харківський національний автомобільно-дорожній університет. опубл. 25.07.2012, Бюл. №14/2012.

6. Пат. 112094 Україна, G 08 G 1/09. Спосіб визначення тривалості елементів та циклу світлофорної сигналізації / Денисенко О. В.; заявник і патентовласник Харківський національний автомобільно-дорожній університет. опубл. 25.07.16, Бюл. № 14/2016.

\section{References}

1. Levashev, A.G., Mikhaylov, A.Yu, Golovnikh, M. (2007). Proektirovanije regulirujemykh peresechenij [Projection of adjustable crossings]. Irkutsk: Publishing house of IRGTU [in Russian].

2. Pleshentsev, V.S., Dmitriyeva, E.V., Sotskov, D.A. (2006). Diagnostirovanije transportnykh potokov federalnoj avtotrassy «Volga M-7» [Diagnosing the traffic flows of federal highway «Volga M-7»]. Organizatsiia i bezopasnost dorozhnogo dvizheniia $\mathrm{v}$ bolshikh gorodakh sbornik statei 7-i mezhdunarodnoi nauchno-prakticheskoi konferentsii posviashchennoi 70-letiiu MVD Rossii Sankt-Peterburg 21-22 sentiabria Traffic organization and safety in big cities : the proceedings of the 7th international scientific and practical conference devoted to the 70 anniversary of Ministry of Internal Affairs of the Russian Federation.St. Petersburg, on September 21-22, 27-31 [in Russian]. 
3. Barskii, I.V. (2006)/ Komplex registratcii izobrazhenija i skorosti (KRIS-1) [The complex of image and speed recordings (KRIS1)]. Organizatsiia i bezopasnost dorozhnogo dvizheniia $v$ bolshikh gorodakh sbornik statei 7-i mezhdunarodnoi nauchno-prakticheskoi konferentsii posviashchennoi 70-letiiu MVD Rossii -Traffic organization and safety in big cities : the proceedings of the 7th international scientific and practical conference devoted to the 70 anniversary of Ministry of Internal Affairs of the Russian Federation. St. Petersburg, on September 21-22, 157-159 [in Russian].

4. Lukyanitsa, A.A., Shishkin, A.G. (2006). Programmnyj komplex dly mjnitoringa transportnykh sredstv po videoizobrazheniju [The program complex for vehicle monitoring using video images. International Conference Graphicon. Novosibirsk Akademgorodok, Russia. Retrieved from: http://www.graphicon.ru [in Russian].

5. Levterov, A.I, Denisenko, O.V., Yaruta, A.M. Sposib vyznachennja parametriv transportnykh potokiv u zoni perekhrestia [A method of determining the parameters of traffic flows in the intersection zone] Pat. Ukraine, no. 71913, 2012[in Ukrainian].

6. Denisenko, O.V. Sposib vyznachennja tryvalosti elementiv ta tysku svitofornoss signalizatsii [A method for determining the length of elements and the traffic light signalling cycle]. Pat. Ukraine, no. 112094, 2016 [in Ukrainian].

Denisenko Oleg Vasilyevich, PhD, Assoc. Prof., Department of Transport Systems and Logistics

Kharkiv National Automobile and Highway University, 25, Yaroslav Mudry St., Kharkiv, Ukraine, 61002, phone +38 050-936-61-03, denisenko.oleg52@gmail.com

\section{ПІДВИЩЕННЯ ЕФЕКТИВНОСТІ ВИЗНАЧЕННЯ ЕЛЕМЕНТІВ ЦИКЛУ СВІТЛОФОРНОГО РЕГУЛЮВАННЯ}

\section{Денисенко О.В., ХНАДУ}

Анотація. Розглянуто новий підхід до визначення параметрів руху транспортних засобів (T3) одночасно по всіх смугах руху на вході й виході регульованого перехрестя. Розкрито особливості сучасної організачії моніторингу транспортних потоків (ТП) на локальних об 'єктах вулично-дорожньої мережі міста. Надано порівняльні характеристики детекторів транспорту, описано особливості контролю і виміру найбільи важ- ливих параметрів руху Т3, а також проаналізовано їх основні достоїнства $і$ недоліки у плані вживання в автоматизованих системах. В якості аналога розглянуто найбільш перспективний спосіб визначення параметрів руху ТП в зоні перехрестя, оснований на багатопроменевому лазерному скануванні його підходів. Подано запропонований спосіб $і$ алгоритм визначення елементів циклу світлофорного регулювання (СР) в умовах динамічної зміни параметрів руху ТП $i$ адаптивного реагування системи на ситуацію. Розглянуто можливості підвищення ефективності способу-аналога за рахунок збільшення числа контрольованих зон, щзо забезпечує підвищення точності визначення тривалості основних $i$ проміжних тактів та оптимізаџію параметрів ицклу регулювання для конкретних умов. Визначення часу дії основних і проміжних тактів за точними вимірами, а не за приблизними розрахунками усереднених значень параметрів, дає можливість у ряді випадків зменшити втрати часу в изиклі регулювання $i$ підвищити ефективну тривалість фаз регулювання. Приведено варіант спрощеної структури пристрою для реалізаиіі запропонованого способу й ефективної обробки вихідної інформації, показано працездатність алгоритмів $i$ можливість їх технічної реалізації. Показано перспективу розширення функціональних можливостей запропонованого способу за рахунок одночасного визначення додаткових параметрів прогнозування стану ТП на перехресті $і$ критерії очінки якості СР, таких як: середня затримка TC, ступінь насичення смуг руху $i$ пропускна спроможність перехрестя. Гнучка технологія $i$ комплексна оцінка режимів СР дозволяє в динаміці (у реальному масштабі часу) здійснювати як параметричну адаптацію (оптимізацію елементів циклу), так $і$ структурну або комбіновану адаптацію за рахунок структурної реорганізації схем управління руху.

Ключові слова: транспортний потік, транспортний засіб, регульоване перехрестя, пристрій розгортання, лазерний промінь, ичикл.

\section{ПОВЫШЕНИЕ ЭФФЕКТИВНОСТИ ОПРЕДЕЛЕНИЯ ЭЛЕМЕНТОВ ЦИКЛА СВЕТОФОРНОГО РЕГУЛИРОВАНИЯ}

\section{Денисенко О.В., ХНАДУ}

Аннотация. Рассмотрен новый подход к определению параметров движения транспортных средств (ТС) и комплексной оценке режимов светофорного регулирования (CP), который учитывает условия динамичного перераспределения транспортных потоков (ТП) в зоне перекрестка, что обеспечивает усовершенствование технологии управления светофорной сигнализации (CC).

Ключевые слова: транспортный поток, транспортное средство, регулируемый перекресток, устройство развертки, лазерный луч, ияикл. 